\title{
The Influence of Service Quality Dimensions on Organizational Excellence (Perspective of Employees within Kuwaiti Commercial Banks)
}

\author{
Salah A. Alabduljader ${ }^{1}$ \\ ${ }^{1}$ Faculty Member of Management and Marketing, Department Business Administration College, Kuwait \\ University, Kuwait \\ Correspondence: Salah A. Alabduljader, Faculty Member of Management and Marketing, Department Business \\ Administration College, Kuwait University, Kuwait.
}

Received: August 25, 2018

doi:10.5539/ibr.v11n10p149
Accepted: September 21, $2018 \quad$ Online Published: September 26, 2018

URL: https://doi.org/10.5539/ibr.v11n10p149

\begin{abstract}
Current study aimed at examining the influence of service quality dimensions on the organizations' ability to reach excellence. Quantitative method was adopted through the questionnaire as a tool. Individuals within commercial banks in Kuwait were retrieved to form the sample of the study. A total of (60) individual responded properly to the questionnaire. The following results were reached:

1- Results indicated the nature of sample to be totally normal with a tendency towards young ages, thoughts and orientations.

2- There appeared a significance that is statistical in nature from service quality dimension and organizational excellence. It meant that service quality along with its dimensions can help in achieving excellence among organizations.

3- All of the study hypotheses were accepted considering that the R value came to be statistically influential. The most influential variables of service quality on organizational excellence appeared to be responsiveness.

Study recommends increasing the awareness regarding service quality and its importance in developing organizational performance. Also, it is recommended for commercial banks to support their CRM strategies in a way that matches between higher service quality and increased customer satisfaction.
\end{abstract}

Keywords: organizational excellence, service quality, quality management

\section{Introduction}

Through the liberation, privatization and globalization era (LPG) most organizations are doing its best to achieve the organizational goals, preserve a god level of employee retention and achieve the best organizational results there is. Many organizations now are focusing on reaching the so called organizational excellence through doing a lot of re-polishing and refining of the internal systems as well as have the effort to tackle and deal with the external risks that the organization might be exposed to (Sahoo and Sahu, 2009).

According to Abasi and Esmaeeli (2012) these days, accomplishing excellence in organizations is essential in light of the fact that, changes in worldwide markets, has confronted associations with various difficulties. The mystery of survival in associations is focusing on need and desires of clients and partners. Associations should be overseen effectively and astutely with open view to condition, the other hand, progressively, emersion of vast and little rivals in various areas of industry and administration, limiting business sector, changing meaning of association crowd from client to partner, focus a providing need and desires of partners, causes attempt for hierarchical greatness. On this side, amid late decades, scholars of administration science, depending on pioneer associations encounters, persistently have been searching for answers for enhance the circumstance and development to perfection. Their examined and looks into have prompted make apparatuses, for example, CRM, PM, SIX SIGMA, ISO, BSC, 5S and TQM.

\section{Problem Statement}

Service itself in addition to its quality appeared to be very influential in making a food reputation for the 
organization. The quality of the service is the main engine that makes customers seek this service, put good words on it, spread the word for other individuals and gain the loyalty of the customer for the benefit of the organization.

When it comes to organizational excellence; one may try to identify the basics of gaining a good way to reach organizational excellence. There have been many tries to highlight the main factors that may influence the organizational achievement of excellence (Kazemi et al, 2011).

From the perspective of Hui and Chuan (2002) there are nine approaches which can be developed in order to reach organizational excellence which are (employee participation, motivation, management ethics and values, learning, innovation, job commitment, and good working relations). Bowden (2000) saw those managing employees' values and believes may lead the organization to excellence. Hussain et al. (2010) stated that reaching organizational excellence can be reached through customer satisfaction and employee motivation in addition to the healthy work environment.

Goetsch and Davis (2014) stated that managing quality and improving its standards can be seen as a source of organizational excellence. On the other hand, Shirvani and

Javad Iranban (2014) noted that reaching organizational excellence can be reached through increasing the level of quality which in its turn can positively influence the organizational performance and the productivity of the human factor leading to excellence.

Based on the above argument, current study aims at examining the influence of service quality dimensions on the organization's ability to reach excellence. Current study hypothesize that dimensions of service quality (empathy, reliability, tangibility, responsiveness, and assurance) can be considered as one of the drivers that may push the organizational wheel towards excellence through improving employees' performance, customer satisfaction and consumer loyalty.

\section{Aims and Objectives}

Main aim of current study is to examine the influence of improving service quality dimensions within commercial banks in Kuwait on the banks' ability to achieve organizational excellence. This aim will be achieved through the following:

- Highlight the relationship between service quality and organizational excellence

- Examine the level of awareness of service quality dimensions among employees and managers in banks

- Highlight the influence of services quality and its dimensions on ability to achieve organizational excellence.

\section{Literature Review}

\section{a) Introduction}

Consumers have increasingly become concerned about quality of products (Babakus, \& Boller, 1992). However, quality as a concept has been defined in different ways by researchers. For example, Berry et al. (1994) consider quality as the attribute of exceeding or satisfying customer expectations and requirements. In this way, Berry et al. (1994) suggest that the quality of a service can only be judged by the customer and as such it should be approached from the customer's perspective. For Brady and Cronin (2001) quality should be considered from the user-based perspective to refer to the "fitness for use" and from the manufacturing-based perspective as referring to "conformance to requirements. In another study, Brady and Cronin (2001) identified five approaches to quality: the product-based approach to economics; transcendent approach of philosophy; the value-based approach from the operation management perspective; the manufacturing-based approach; and user based approach of operation management, marketing and economics.

From the transcendent approach, quality means achieving "innate excellence". From this approach, quality is an indicator of high achievement and uncompromising standards, universally recognized through experience. From the product-based approach, quality refers to the "measurable and precise variable". From this view, quality reflects differences in the attribute or quantity of ingredients meaning that organizations can only achieve higher quality product/service by incurring high expenses. From the user-based approach quality is defined from the customer satisfaction perspective in those higher quality products or services means meeting consumers' preferences or their needs. Quality as approached from the manufacturing-based approach refers to "making a product or service right the first time". This approach is concerned with the manufacturing and engineering practice. Lastly, from the value-based approach, researchers define quality in terms of price and cost by perceiving it as a function of cost and price. 
In the service sector where delivery, consumption and production occur simultaneously such as in banks, the concept of service quality has increasingly become important to customers. According to Brady, Brady and Cronin (2002) services sector such as hotels and banks recognize how sensitive customers have become when it comes to the quality of service. They recognize that service quality can be a source of competitive advantage and means to achieve organizational excellence (Brown, Churchill \& Peter, 1993). In this sector, perceived service quality as defined by several researchers focuses on meeting customers' requirements and needs and how well the delivered service meets customers' expectations. It is argued that for an organization to maintain delivering a quality service, it should first recognize what customers consider as quality (Cerman, 1990). According to Cerman (1990), there are two categories of service quality: functional quality and technical quality. Technical quality primarily focuses on the entire process of delivering a service; while technical quality emphasizes on what is obtained from the service by consumers. Perceptions of service quality by individuals who use and consume them and those who offer them are the outcomes of comparison between the perceived service and the expected service (Parasuraman et al., 1985).

Delivering quality service is recognized as one of the key challenges being experienced by banks and other organizations within the service section. According to Cerman (1990) the success of an organization operating within the globalized emerging and competitive service sector is largely dependent on the delivery of quality service. According to Carman (1990), quality is an essential element when it comes to meeting customer needs and achieving customer satisfaction. This dynamic state is associated with people, service, environments and products that exceeds or meets expectations. It also entails embracing the extent of the impact a firm may have on the society, stakeholders, and environment. Cronin, and Taylor (1992) opines that customers tend to judge a service a high or low quality by assessing it to determine whether it meets or exceeds their expectations. As perceived by customers, service quality is the degree of discrepancy between their perceptions and their desires or expectations. As such, service delivered concerns where, how and when the service is delivered to consumers.

Services are identified with four unique characteristics that separate them from goods. These characteristic are widely used to examine the behaviors of consumers of the service and to come up with service marketing strategies. These characteristics are intangibility; inseparability; perishability; and heterogeneity.

The concept of intangibility denotes that services are activities, satisfactions and benefits that are offered during the selling of goods or provided for sale. They are conceptualized as activities that are not tested, felt, seen, smelt or heard. It is impossible to evaluate them before purchasing or consuming them. Examples include consulting, restaurants, hotels, banks, hospitals, and fast food centers.

Inseparability concerns the simultaneous consumption and delivery of a service. It provides that services are often produced and consumed simultaneously. It is argued that inseparability enables customers to shape the quality and performance of service. Unlike physical goods which are produced and transformed into products and distributed via many resellers, services cannot be isolated from their providers meaning that the service provider must be present to provide the service. Again, services cannot be preserved for later consumption like it is the case with goods. In addition, it is important for the consumer to be physically present. This inseparability of consumption and production demonstrates the importance of ensuring quality services are delivered to customer. As such marketers of a service are required to develop technical and task-related competence of service personnel as well as seek for the input of the skilled personnel to help improve the inter-personal and marketing skills.

Heterogeneity concerns the variability in the delivery of a service. Unlike tangible goods, services are not standardized. They are executed by individuals who differ in the way they execute them. Heterogeneity of the services means that customers differ in their demands as well how they experience a service. Perishability of a service refers to the idea that services cannot be carried forward and stored for use in future. It emphasizes that services are time important and time dependent and that they are perishables. They are performance, deeds or acts which perish when not consumers. Their consumption must occur simultaneously.

\section{b) Service Quality}

There are several models that identify parameters that can be used to measure service quality. One of the widely used and acknowledged models in the service sector is the SERVQUAL model developed by Parasuraman et al. (1988). In this model, Parasuraman et al. $(1985 ; 1988)$ identified parameters that can be used to identify and measure service quality received by consumers. The SERVQUAL instrument encompasses 22 statements used to assess he consumers' expectations and perceptions with regard to quality of service provided to customers. It was developed by Parasuramen et al. (1988) asked respondents to rate their level of disagreement or agreement with certain statements. The perceptions of consumers towards the service being offered are based on service received. 
On the other hand, expectations of consumers are based on information received and past experiences. The 22 statements represents dimensions of service quality which are identified as reliability, empathy, assurance; responsiveness; and tangibility (Carman, 1990; Cronin, \& Taylor, 1992; Dabholkar, Thorpe, \& Rentz, 1996; Dotchin, \& Oakland, 1994; Frost, \& Kumar, 2000; Finn, \& Lamb 1991)

\section{c) Service Quality Dimensions}

\section{i) Tangibles}

Parasuraman et al. (1985) held that services are tangibles and consumers develop a perception of service quality through comparing its tangible elements, including the appearance of the equipment, physical facilities, communication materials and personnel. Accordingly, tangibility refers to the appearance of the equipment, written materials, personnel, and physical facilities. Parasuraman et al. (1985) suggested that tangibility can be measured using questions related to the facilities and physical layout offered by FFR. Within the context of private sector banks, Ananth et al. (2011) referred to tangibility as employees, physical facilities, modern looking equipment, and the visually appearance of employees and materials.

\section{ii) Reliability}

Reliability concerns the ability of an entity to accurately and dependably undertake the promised service. It determines how an entity can deliver on its promises about service provision and delivery, pricing, and problem resolutions. It reflects how customers' problems are handled; providing services as promised; performing services as expected; and maintaining error-free record. It also entails accurate fulfilment of the order, accurate quotation; accurate record; accurate calculation of commissions; accurate billing; and keeping services as promised. Parasuraman et al., 1988) noted that customers tend to prefer firms that keep their promises about core service attributes and service outcomes. Reliability is identified as important element in in any conventional service and in service sectors such as banking (Parasuraman et al., 1988).

\section{iii) Responsiveness}

Responsiveness refers to the willingness to offer prompt service and help customers. It also refers to the readiness of the organization to offer a service. It emphasizes the promptness and attentiveness with customers' questions, requests, promises and complaints. It reflects the timeliness of service and involves understanding customers' wants and needs, individual attention given to customers by the staff, convenient operating hours, and attention to customers' safety and problems in their transactions. It reflects the notion of ability and flexibility to customize services to the needs of the customer (Parasuraman et al., 1985; El Saghier, 2015).

\section{iv) Assurance}

Assurance means inspiring confidence and trust. It refers to the knowledge of courtesy by employees and the firm's ability to inspire confidence and trust (Parasuraman et al., 1985). It is particularly relevant to services perceived by customers as involving high rising. Confidence and trust can be embodied in individuals who link customers to a firm. Therefore, employees recognize the importance of creating confidence and trust in customers as a way to bolster customer loyalty and gain a competitive advantage. Within the context of British banks, Sadek et al. (2010) assurance means the friendly and polite staff, interior comfort, provision of financial advice, experienced and knowledgeable management team and ease of access to important account information.

\section{v) Empathy}

Empathy refers to the provision of individualized and caring attention by a firm to customers as a demonstration of commitment to meet and satisfy customers' needs. Empathy adds to the trust and to the trust and confidence in customers and helps increased customer loyalty (Paraasuraman et al., 1985). Within the context of private sector banks, Ananth et al. (2011) referred to empathy as giving customers' attention, individual attention, having the best interest at hear; dedicating operating hours to serving customers and understanding specific needs of customers.

\section{Organizational Excellence}

Organizational excellence have been conceptualized differently be different researchers. According to Dabholkar, Thorpe, \& Rentz, (1996) organizational excellence involves efforts by an organization to establish a framework of processes and standards aimed at engaging and motivating employees to deliver services and products that fulfil customer requirements. Organization excellence can also be conceptualized the successful integration of personnel, infrastructure and technology. It is a result of transformational and transitional activities. Elsewhere, Harrington (2005) observed that organizational excellence refers to the organization's ability to excel in all the activities and strategies that it leads through reaching a state of zero error and failure. Harrington (2005) noted 
that the idea of organization excellence revolves around the ongoing organizational trials to build a type of internal framework that is based on standards and procedures. According to Harrington (2005) those standards and procedures are designed to push and encourage the employees to present the best and most accurate outcomes in terms of the products and services that they deliver. In other words, employees will be able to meet the customers' expectations with full awareness and understanding of the organization's objectives and vision. Harrington (2005) further advanced that organizational excellence is based on five main pillars: a) process management b) project management c) change management d) knowledge management and e) resource management. Harrington added that we have to deal with our procedures and persistently enhance them for they are the way we work together. We have to deal with our tasks for that is the way we acquire real changes in our procedures and today, most associations are completing an extremely poor activity of venture administration as exhibited by the high disappointment rate of undertakings. We have to deal with the association so it is set up for the disarray that it is being subjected to because of the greatness and amount of changes that must be executed. We have to deal with the association's learning that is the association's most important resource. It is the association's learning that gives an association its upper hand. We have to deal with our assets and resources for they drive our business come about .

For Agarwal and Vrat (2016) organizational excellence is the state where the organization is in total control of its assists and has a good relation with the external environment of its business including the market and the competitors. For Arussy (2008) excellence refers to the quality, state, or condition of excellence. Arussy (2008) advanced that organizational excellence is an everyday event achieved whenever an organization succeeds in exceeding expectations. In another study, McAdam (2000) argued that organizational excellence can be tested on two levels which are a) customer excellence referring to the organization's ability to satisfy its customers and b) business excellence referring to the organization's ability to hold on a legitimate and well-built performance in addition to the concept of market growth and relations with the competitors. In another study, Cameron and Quinn (2011) suggested that organizational excellence should be arranged based on the following criteria :

- Customer excellence referring to the organization's ability to satisfy its customers and business excellence referring to the organization's ability to hold on a legitimate and well-built performance in addition to the concept of market growth and relations with the competitors.

- Stability versus Flexibility: speaks to debating perspectives all together, control, and expert, versus assorted variety, singular activity, and hierarchical versatility.

- Internal versus External: alludes to strife between accentuation on prosperity of individuals in an association and accentuation on advancement of the association itself .

- Means versus ends: accentuation on process like arranging and objective setting.

According to Frost, and Kumar (2000) successful organizational outcomes requires improvement in the following key areas: rewards; information; people, structure learning systems (training and knowledge), and work processes (linkage and interaction of workflows). Information includes decision support, measures, and metrics. Structures include responsibilities, accountabilities and roles of each functional area. People include total human capital in an organization and rewards include incentives and compensation. According to McMaulle, Brown, and Cliffe (2001), the pursuit of organizational excellence by an organization can strengthen its prestige and appeal both externally and internally. Any additional costs of overhead and infrastructure can be compensated with greater returns which are gained when customers are satisfied, employees are engaged, and operations and efficient. This was organized profiled in the book by Peters and Waterman. In this book, Peters and Waterman revealed that companies that applied best practices and activity of organization excellence showed better performance than the S\&P 500 and Dow Jones Industrial Average. Furthermore, as demonstrated in the effect of the Baldrige on organizational performance, applicants in the Baldrige Performance excellence program used Baldrige Excellence Framework and recorded a high benefit-to-cost ratio. The benefit-to-cost ration associated with using Baldrige Excellence Framework was found as 3.0 to 1; a benefit-to-cost ratio of 107 to 1 for financial gains associated the increase in customer satisfaction.

\section{Drivers of Organizational Excellence}

As identified Darling and Nurmi (1995) there are three attributes of organizational excellence or organizational success attributes: care of customers/customer satisfaction, constant innovation; and committed employees.

Hui and Chuan (2002) identified aspects of organizational excellence and noted that it encompasses strong mission and vision; forming strategies and policies; management values and ethics; providing customer care; empowerment and innovation; people well-being; commitment to excellence; people development; use of new 
technologies; suppliers and business partnerships; fostering good working relations; service and responsibilities to the public. Sasmita and Nayantara (2003) supports this view by arguing that firm that seeking for excellence should strive to link excellence to activities and processes; evaluate excellence; empower employees; pass vision to employees; instill technology and encourage learning. Similarly, Goetsch and Davis (2014) noted that organizational excellence depends on relationship with customers, organizational competitive strategy and innovation (technology). Goetsch and Davis (2014) further observed that commitment to quality, employee empowerment, and employees' involvement, critical success factors for organization to realize organizational excellence and achieve success. McNamara (1997) also argued that a firm can achieve excellence by being informed about financial structure, profitability, core competences customer reputation and profitability. McNamara (1997) further observed that being aware of the above attributes can enable an organization to achieve organizational excellence.

\section{Service Quality and Organizational Excellence within Commercial Banks}

Studies have demonstrated the relevant and significance of service quality in achieving organizational excellence within commercial banks within different contexts.

Within the Chinese context, Duncan and Elliot (2002) noted that service quality significantly impact on the short-term profitability of banks and their financial performance. Duncan and Elliot (2002) observed that service quality may impact on customer loyalty and customer satisfaction and that its impact increases as competition intensifies. Similar, Chang et al. (2017) used a sample of 20 state-owned commercial banks in China to investigate the relationship between service quality, efficiency, and customer satisfaction in state-owned commercial banks in China. The aim was to link service quality with organizational excellence with customer satisfaction as the mediating variable. Result confirmed that service quality positively impacts on customer satisfaction and efficiency and that customer satisfaction mediates the relationship service quality and customer satisfaction.

In a similar study, Hussain, Khalid, and Waheed (2010) examined the organizational practice that could enable an organization to achieve business excellence. Hussain, Khalid, and Waheed (2010) further investigated the role of quality assurance, appraisal mechanism, managerial traits, quality infrastructure, and profit-orientation of a firm on organizational excellence, organizational culture, and employees' motivation within the Pakistan banking sector. Results confirmed that banks can achieve organizational excellence, satisfy customers and motivate employees by incorporating quality initiatives and appraisal mechanism aimed at improving service quality.

\section{Methodology}

\section{a) Methodological Approach}

In order to reach the objectives of current study, researcher has chosen to follow the quantitative method. Based on that, current research appeared to be deductive and positivist in its nature and philosophy.

\section{b) Tool of Study}

Questionnaire was employed to be the tool of current study. Researcher has built the questionnaire depending on previous studies and articles which have taken into account one or more variables of the study. The questionnaire was divided into two sections; the first considered the demographic variables of study (age, gender, experience and position) while the other section presented the paragraphs of the study according to liker $5^{\text {th }}$ scale.

\section{c) Population and Sample}

Current study considered all managers, leaders and head departments within commercial banks in Kuwait to be the population of the study carried out. A convenient sample from the following banks was chosen.

\begin{tabular}{|c|}
\hline Commercial Banks of Kuwait \\
\hline National Bank of Kuwait \\
\hline Gulf Bank of Kuwait \\
\hline Commercial Bank of Kuwait \\
\hline Al-Ahli Bank of Kuwait \\
\hline Bank of Bahrain and Kuwait \\
\hline Burgan bank \\
\hline
\end{tabular}

The final sample of the study reached (72) manager, leader and head department from the aforementioned commercial banks in Kuwait. However, (60) individuals responded to the questionnaire, this indicated that 83.3\% 
referring to the response rate as statistically proper.

\section{d) Hypotheses of Study}

\section{Main Hypothesis:}

There is a statistically significant influence of service quality on organizational excellence

\section{Sub-Hypotheses:}

H1: There is a statistically significant influence of Tangibles on organizational excellence

H2: There is a statistically significant influence of Reliability on organizational excellence

H3: There is a statistically significant influence of Responsiveness on organizational excellence

H4: There is a statistically significant influence of Assurance on organizational excellence

H5: There is a statistically significant influence of Empathy on organizational excellence

\section{Results}

a) Demographic Results

\section{i) Age}

Table 1. Sample characteristics according to age

\begin{tabular}{|c|c|c|c|c|c|}
\hline & & Frequency & Percent & Valid Percent & Cumulative Percent \\
\hline \multirow{5}{*}{ Valid } & $22-27$ & 9 & 15.0 & 15.0 & 15.0 \\
\hline & $28-33$ & 29 & 48.3 & 48.3 & 63.3 \\
\hline & $34-39$ & 15 & 25.0 & 25.0 & 88.3 \\
\hline & +40 & 7 & 11.7 & 11.7 & 100.0 \\
\hline & Total & 60 & 100.0 & 100.0 & \\
\hline
\end{tabular}

According to table (1), it can be read from the analysis that almost half of the sample $48.3 \%$ was individuals within the age range of 28-33 years with frequency of 39 individuals. This indicated the young age of respondents which is considered to be healthy for organizations; given that organizations with employees who are young in their age are welling to come up with innovative ideas. The second rank of sample characteristics according to age was the range of $34-39$ forming $25 \%$ of the sample and frequency of 15 individuals. This age is also seen to be relatively young which will also help the organization reach the best and most accurate performance there is.

\section{ii) Experience}

Table 2. Sample characteristics according to experience

\begin{tabular}{rlrrrr}
\hline & & Frequency & Percent & Valid Percent & Cumulative Percent \\
\hline Valid & $2-5$ & 17 & 28.3 & 28.3 & 28.3 \\
& $6-9$ & 23 & 38.3 & 38.3 & 66.7 \\
& $10-13$ & 15 & 25.0 & 25.0 & 91.7 \\
& +14 & 5 & 8.3 & 8.3 & 100.0 \\
& Total & 60 & 100.0 & 100.0 & \\
\hline
\end{tabular}

Examining table (2), it can be seen that the through the analysis; $38.3 \%$ of respondents were individuals who had an experience ranging between 6-9 years. Following that range was individuals who had an experience of 25 years forming $28.3 \%$ of the sample with frequency of 17 individuals.

\section{iii) Gender}

Table 3. Sample characteristics according to gender

\begin{tabular}{llrrrr}
\hline & & Frequency & Percent & Valid Percent & Cumulative Percent \\
\hline Valid & Males & 30 & 50.0 & 50.0 & 50.0 \\
& Females & 30 & 50.0 & 50.0 & 100.0 \\
& Total & 60 & 100.0 & 100.0 & \\
\hline
\end{tabular}

Table (3) presented the sample characteristics according to gender. It appeared through the analysis respondents were equally divided between males and females forming $50 \%$ of each type. This can indicate that both males and females were equally interested in the topic.

\section{b) Questionnaire Analysis}


Table 4. Descriptive Statistics of Questionnaire statements

\begin{tabular}{|c|c|c|c|c|c|}
\hline Statement & $\mathrm{N}$ & Minimum & Maximum & Mean & $\begin{array}{c}\text { Std. } \\
\text { Deviation }\end{array}$ \\
\hline \multicolumn{6}{|c|}{ Organizational Excellence } \\
\hline $\begin{array}{l}\text { Organizational excellence is based on defining resource requirements } \\
\text { (financial, asset, technology, knowledge, transportation) }\end{array}$ & 60 & 2 & 5 & 3.95 & .746 \\
\hline There has to be a strategy to manage resources effectively & 60 & 1 & 5 & 3.87 & .791 \\
\hline $\begin{array}{l}\text { Minimizing the adverse impact of products and services on the } \\
\text { environment and community leads to organizational excellence }\end{array}$ & 60 & 2 & 5 & 3.78 & .739 \\
\hline $\begin{array}{l}\text { Creating alternative and emerging technology and related cost-benefit } \\
\text { to the organization can support organizational excellence }\end{array}$ & 60 & 1 & 5 & 3.68 & .854 \\
\hline $\begin{array}{l}\text { Continuous improvement are important to establish organizational } \\
\text { excellence }\end{array}$ & 60 & 2 & 5 & 3.93 & .634 \\
\hline \multicolumn{6}{|l|}{$\begin{array}{c}\text { Service Quality Dimensions } \\
\text { Tangibles }\end{array}$} \\
\hline $\begin{array}{l}\text { Organizations seeking excellence should have up-to-date equipment } \\
\text { and tools }\end{array}$ & 60 & 2 & 5 & 3.90 & .681 \\
\hline Technology is important to achieve excellence & 60 & 2 & 5 & 3.82 & .770 \\
\hline Work environment and facilities have to be visually appealing & 60 & 1 & 5 & 3.70 & .889 \\
\hline There should be a code for employees' dress and neatness & 60 & 2 & 5 & 3.83 & 668 \\
\hline Environment should meet the nature of the service presented & 60 & 1 & 5 & 3.50 & 1.097 \\
\hline \multicolumn{6}{|l|}{ Reliability } \\
\hline $\begin{array}{l}\text { Keeping promising to present the service on time can help in } \\
\text { achieving excellence }\end{array}$ & 60 & 1 & 5 & 3.52 & 1.081 \\
\hline Quick response to consumers' complains is a key issue & 60 & 3 & 5 & 3.92 & .591 \\
\hline Organizations seeking excellence should be dependable & 60 & 1 & 5 & 4.02 & .725 \\
\hline Keeping accurate records is an important thing for excellence & 60 & 2 & 5 & 3.88 & .666 \\
\hline Organizations should be ready in case of risks or dangers & 60 & 1 & 5 & 3.60 & 1.012 \\
\hline \multicolumn{6}{|l|}{ Responsiveness } \\
\hline Services are provided to consumer in set dates & 60 & 1 & 5 & 3.77 & .851 \\
\hline $\begin{array}{l}\text { To reach excellence it is expected from organizations to present } \\
\text { prompt services }\end{array}$ & 60 & 2 & 5 & 3.87 & .724 \\
\hline Employees in the organization are always welling to serve & 60 & 2 & 5 & 3.97 & .581 \\
\hline $\begin{array}{l}\text { Excellence means that the organization is never too busy to serve a } \\
\text { client }\end{array}$ & 60 & 2 & 5 & 3.95 & .565 \\
\hline Customers are always happy & 60 & 2 & 5 & 3.78 & .885 \\
\hline \multicolumn{6}{|l|}{ Assurance } \\
\hline $\begin{array}{l}\text { Excellence means to have mutual feelings of trust between employees } \\
\text { and consumers }\end{array}$ & 60 & 2 & 5 & 3.82 & .792 \\
\hline Consumers don't feel they are going to be ripped off & 60 & 1 & 5 & 3.78 & .783 \\
\hline Employees have the adequate support o do their job well & 60 & 1 & 5 & 3.88 & 666 \\
\hline Excellence is when employees are polite and professional & 60 & 2 & 5 & 3.92 & 671 \\
\hline Consumers feel that the organization is always taking their side & 60 & 2 & 5 & 3.93 & 686 \\
\hline \multicolumn{6}{|l|}{ Empathy } \\
\hline $\begin{array}{l}\text { Excellence is when the organization is able to give consumers an } \\
\text { individual attention }\end{array}$ & 60 & 2 & 5 & 3.97 & .486 \\
\hline Employees are always able to give their consumers personal attention & 60 & 1 & 5 & 3.70 & .908 \\
\hline $\begin{array}{l}\text { With time, employees are expected to be aware of their consumers' } \\
\text { needs }\end{array}$ & 60 & 1 & 5 & 3.62 & .993 \\
\hline $\begin{array}{l}\text { Excellence is when the organization has the interest of consumers' at } \\
\text { heart }\end{array}$ & 60 & 1 & 5 & 3.63 & .938 \\
\hline $\begin{array}{l}\text { Organizations with flexible working hours for consumers are mostly } \\
\text { excellent for them }\end{array}$ & 60 & 1 & 5 & 3.55 & .999 \\
\hline Valid N (listwise) & 60 & & & & \\
\hline
\end{tabular}

Based on table (4), it can be concluded that the respondents' attitudes towards the above statements were positive. They were considered positive given that the means of statement appeared to be greater than 3 which was the mean of the five rating points of the Likert scale. Among all the statement of the questionnaire; the most influential statement appeared to be "Organizations seeking excellence should be dependable" as one of (reliability) statements. This indicated that the reliability and dependability of the organization are among the factors that can help in reaching organizational excellence.

\section{c) Reliability}

A reliability test was carried out using Cronbachs' alpha, The result showed a value of (0.944) for the all items as well as alpha for each variable is greater than accepted percent 0.60 , which is a reasonable value indicating the tool consistency that enhanced its use for the study. 
Table 5. Descriptive Statistics

\begin{tabular}{lrrrrr}
\hline & $\mathrm{N}$ & Minimum & Maximum & Mean & Std. Deviation \\
\hline Tangibles & 60 & 1.80 & 5.00 & 3.8433 & .58927 \\
Reliability & 60 & 2.20 & 5.00 & 3.7500 & .61795 \\
Responsiveness & 60 & 1.60 & 5.00 & 3.7867 & .61049 \\
Assurance & 60 & 2.40 & 5.00 & 3.8667 & .55316 \\
Empathy & 60 & 2.40 & 5.00 & 3.8667 & .53951 \\
Excellence & 60 & 2.20 & 5.00 & 3.6933 & .68045 \\
Valid N (listwise) & 60 & & & & \\
\hline
\end{tabular}

Based on table (5), it can be concluded that the respondents' attitudes towards the above variables of study appeared to be positive. Looking at the mean of each variables it can be seen that all of the variables scored greater the mean of the scale which is (3) referring to those variables as influential.

\section{d) Hypotheses Testing}

\section{2) Main Hypothesis:}

There is a statistically significant influence of service quality on organizational excellence

Table 6. Model Summary

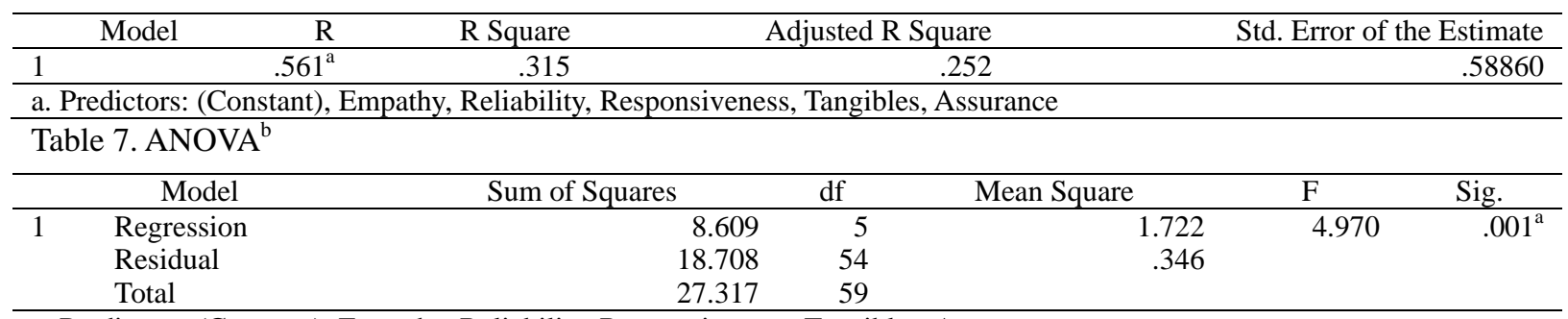

a. Predictors: (Constant), Empathy, Reliability, Responsiveness, Tangibles, Assurance

b. Dependent Variable: Excellence

Table 8. Coefficients ${ }^{\mathrm{a}}$

\begin{tabular}{llrrrrr}
\hline \multirow{2}{*}{ Model } & \multicolumn{2}{c}{ Unstandardized Coefficients } & Standardized Coefficients & \\
\cline { 2 - 7 } & \multicolumn{2}{c}{ B } & Std. Error & Beta & S & Sig. \\
\hline 1 & (Constant) & 1.114 & .596 & .868 & .067 \\
& Tangibles & $-.042-$ & .246 & $-.037-$ & $-.173-$ & .864 \\
& Reliability & .230 & .200 & .209 & 1.149 & .256 \\
& Responsiveness & .444 & .229 & .398 & 1.940 & .058 \\
Assurance & .013 & .265 & .011 & .049 & .961 \\
& Empathy & .038 & .266 & .030 & .144 & .886 \\
\hline
\end{tabular}

a. Dependent Variable: Excellence

Multiple regression was used to test the main hypothesis of the study, it was found that $\mathrm{R}(0.561)$ was the correlation of 'quality service dimensions' and 'organizational excellence'. Also it WAS found that the F value of (4.970) WAS significant at (0.05) level. Thus, the hypothesis was accepted and there is a statistically significant influence of service quality dimensions on organizational excellence .

H1: There is a statistically significant influence of Tangibles on organizational excellence

Table 9. Model Summary

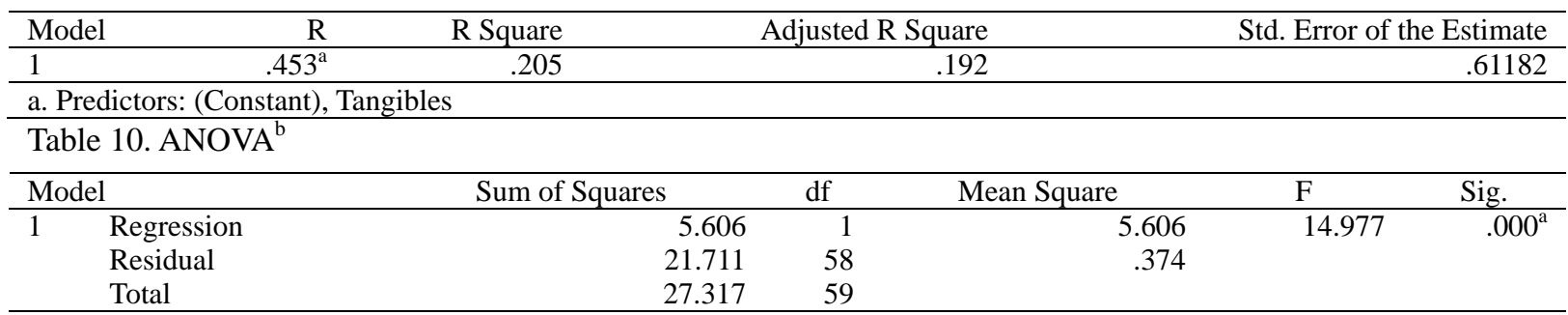

a. Predictors: (Constant), Tangibles

b. Dependent Variable: Excellence 
Table 11. Coefficients ${ }^{\mathrm{a}}$

\begin{tabular}{llrrrrr}
\hline \multirow{2}{*}{ Model } & \multicolumn{2}{c}{ Unstandardized Coefficients } & \multicolumn{2}{c}{ Standardized Coefficients } & & t \\
\cline { 2 - 7 } & \multicolumn{2}{c}{ B } & Std. Error & Big. \\
\hline 1 & (Constant) & 1.683 & .525 & & 3.202 & .002 \\
& Tangibles & .523 & .135 & .453 & 3.870 & .000
\end{tabular}

a. Dependent Variable: Excellence

Linear regression was used to test $1^{\text {st }}$ hypothesis, it was found that $\mathrm{R}(0.453)$ was the correlation of 'tangibles and 'organizational excellence'. Also it was found that F value of (14.977) was significant at (0.05) level. Thus, hypothesis was accepted and there is a statistically significant influence of Tangibles on organizational excellence

H2: There is a statistically significant influence of Reliability on organizational excellence

Table 12. Model Summary

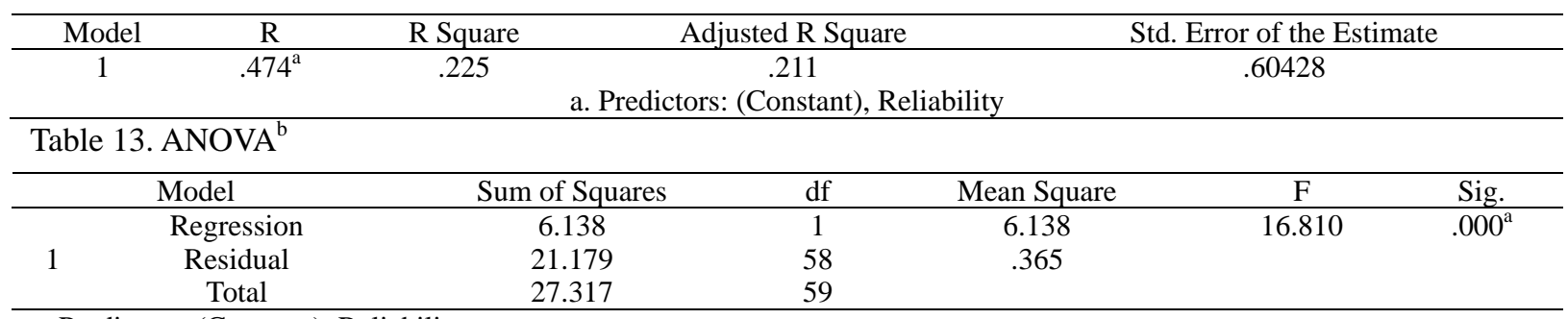

a. Predictors: (Constant), Reliability

b. Dependent Variable: Excellence

Table 14. Coefficients ${ }^{\mathrm{a}}$

\begin{tabular}{ccccccc}
\hline \multirow{2}{*}{ Model } & \multicolumn{2}{c}{ Unstandardized Coefficients } & \multicolumn{2}{c}{ Standardized Coefficients } & t & Sig. \\
\cline { 3 - 6 } & & $\mathrm{B}$ & Std. Error & Beta & & 3.589 \\
\multirow{2}{*}{1} & (Constant) & 1.736 & .484 & .001 \\
& Reliability & .522 & .127 & .474 & 4.100 & .000 \\
\hline
\end{tabular}

a. Dependent Variable: Excellence

Linear regression was used to test $2^{\text {nd }}$ hypothesis, it was found that $\mathrm{R}(0.474)$ was the correlation of 'reliability' and 'organizational excellence'. Also it was found that F value of (16.810) was significant at (0.05) level. Thus, hypothesis accepted, and there is a statistically significant influence of Reliability on organizational excellence

\section{H3: There is a statistically significant influence of Responsiveness on organizational excellence}

Table 15. Model Summary

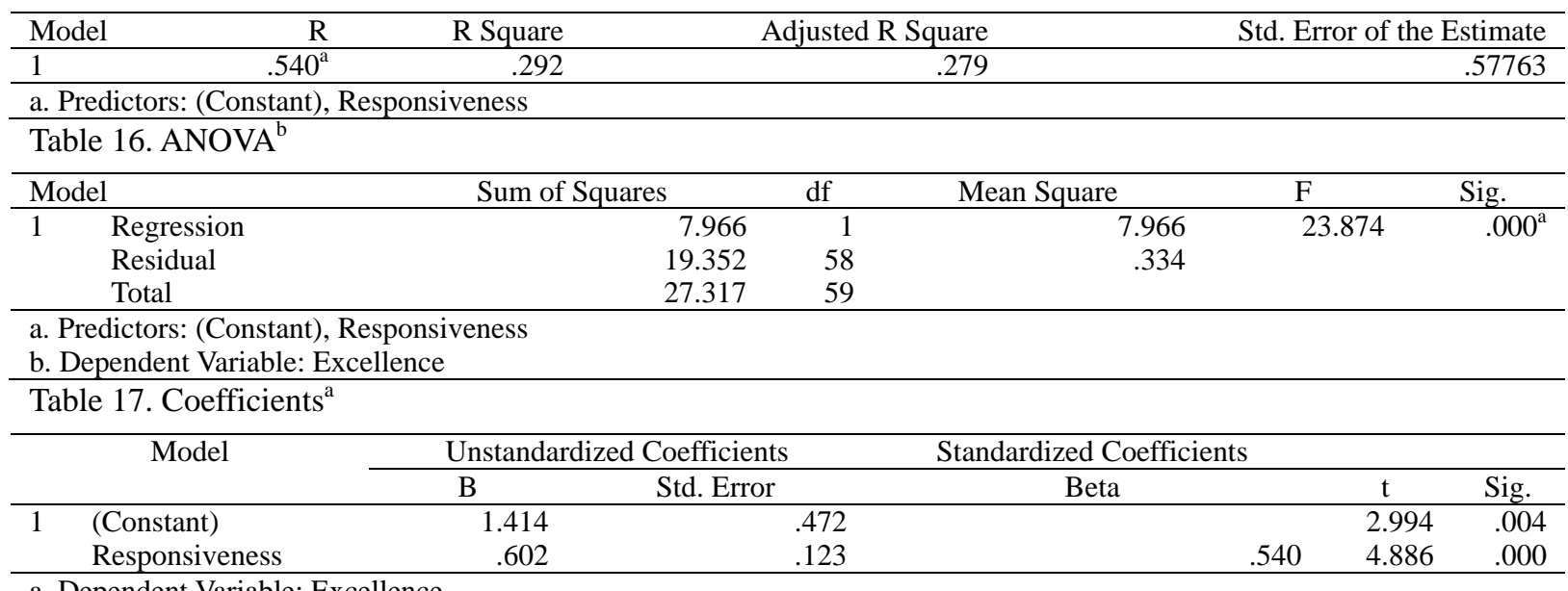

a. Dependent Variable: Excellence

Linear regression was used to test $3^{\text {rd }}$ hypothesis, it was found that $\mathrm{R}(0.54)$ was the correlation of 'responsiveness' and 'organizational excellence'. Also it was found that F value of (23.874) was significant at (0.05) level. Thus, hypothesis was accepted and there appeared a statistically significant influence of Responsiveness on organizational excellence

H4: There is a statistically significant influence of Assurance on organizational excellence 
Table 18. Model Summary

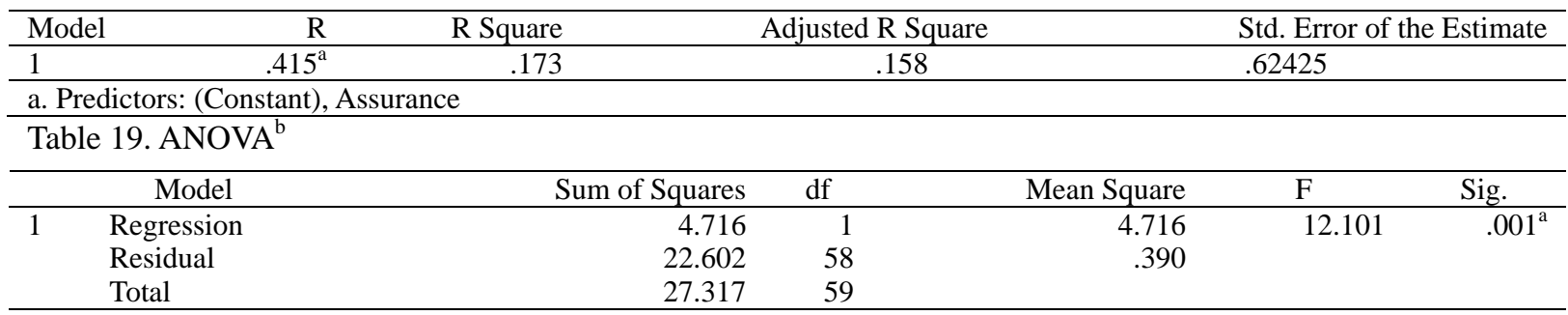

a. Predictors: (Constant), Assurance

b. Dependent Variable: Excellence

Table 20. Coefficients ${ }^{\mathrm{a}}$

\begin{tabular}{|c|c|c|c|c|c|c|c|}
\hline & \multirow[t]{2}{*}{ Model } & \multicolumn{2}{|c|}{ Unstandardized Coefficients } & \multicolumn{4}{|c|}{ Standardized Coefficients } \\
\hline & & B & Std. Error & Beta & & $\mathrm{t}$ & Sig. \\
\hline \multirow[t]{2}{*}{1} & (Constant) & 1.717 & .574 & & & 2.993 & .004 \\
\hline & Assurance & .511 & .147 & & .415 & 3.479 & .001 \\
\hline
\end{tabular}

a. Dependent Variable: Excellence

Linear regression was used to test $4^{\text {th }}$ hypothesis, it was found that $\mathrm{R}(0.415)$ was the correlation of 'assurance' and 'organizational excellence'. Also it was found that F value of (12.101) was significant at (0.05) level. Thus, hypothesis also was accepted, there is a statistically significant influence of Assurance on organizational excellence

H5: There is a statistically significant influence of Empathy on organizational excellence

Table 21. Model Summary

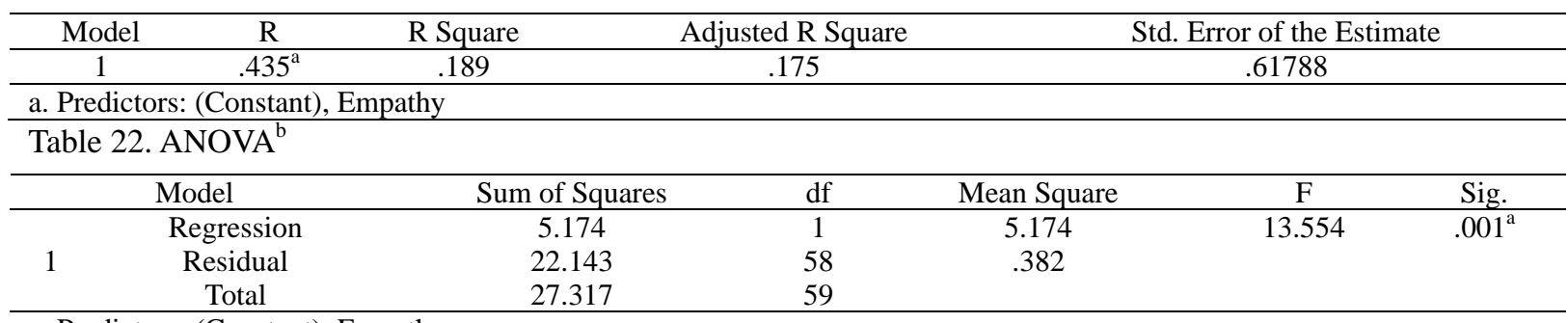

a. Predictors: (Constant), Empathy

b. Dependent Variable: Excellence

Table 23. Coefficients ${ }^{\mathrm{a}}$

\begin{tabular}{|c|c|c|c|c|c|c|}
\hline & \multirow{2}{*}{ Model } & \multicolumn{2}{|c|}{ Unstandardized Coefficients } & \multicolumn{3}{|c|}{ Standardized Coefficients } \\
\hline & & $\mathrm{B}$ & Std. Error & Beta & $\mathrm{t}$ & Sig. \\
\hline \multirow{2}{*}{1} & (Constant) & 1.571 & .582 & & 2.699 & .009 \\
\hline & Empathy & .549 & .149 & .435 & 3.682 & .001 \\
\hline
\end{tabular}

a. Dependent Variable: Excellence

Linear regression was used to test $5^{\text {th }}$ hypothesis, it is found that $\mathrm{R}(0.435)$ was the correlation of 'empathy' and 'organizational excellence'. Also it was found that F value of (13.554) was significant at (0.05) level. Thus, hypothesis was accepted, there is a statistically significant influence of Empathy on organizational excellence

\section{Discussion}

Current study aimed at examining the influence of service quality dimensions on the organizations' ability to reach excellence. Quantitative method was adopted through the questionnaire as a tool. Individuals within commercial banks in Kuwait were retrieved to form the sample of the study. A total of (60) individual responded properly to the questionnaire. The following results were reached:

1- Results indicated the nature of sample to be totally normal with a tendency towards young ages, thoughts and orientations.

2- There appeared a significance that is statistical in nature from service quality dimension and organizational excellence. It meant that service quality along with its dimensions can help in achieving excellence among organizations.

3- All of the study hypotheses were accepted considering that the R value came to be statistically influential.

4- The most influential variable of service quality (Tangibles, Reliability ,Responsiveness ,Assurance ,and Empathy) appeared to as follows: 
- Responsiveness appeared to be the most influential variable of all. It scored an $\mathrm{R}$ value of $\left(.540^{\mathrm{a}}\right)$ appearing as the most influential answered variable by the sample within the questionnaire.

- Reliability came in the $2^{\text {nd }}$ rank with an $\mathrm{R}$ value of $\left(.474^{\mathrm{a}}\right)$ revealing itself as an influential factors that may interfere with the achieving of organizational excellence among organizations.

- Respondents appeared to have the needed awareness regarding service quality and organizational excellence. Given that the study was applied within the commercial banks in Kuwait; and normally banks present services to the client; then the level of awareness is seen to be very important among employees.

\section{a) Role of Tangibility in Increasing Chances for Organizational Excellence}

Through the study, tangibility and tangibles appeared to be influential in helping the organization reaching organizational excellence. Results of study matched what came along with Purcărea et al. (2010) when they argued that tangible quality is among the important factors that help in achieving excellence. The authors saw that having a high level of tangibility within tourism and hospitality industry can aid the process of reaching customer satisfaction through making their journeys memorable; that way the organization would be more able to reach excellence.

Also, study results matched another study by Tohidi and Jabbari (2012), the authors argued that every organization strives for excellence, excellence can be reachable through consumer satisfaction, when the consumer is satisfied, then the organization has found its way to excellence in the market.

\section{b) Reliability Role in Organizational Excellence}

The study has revealed a positive relationship between reliability and the ability of an organization to reach excellence. In that sense, the organization's reliability can help in developing a sustained approach to excellence. Goetsch and Davis (2014) noted to the same idea, they argued that the organizational reliability an influence the nature of quality management within the organization which can lead to sustainability which in turn can be seen as one of the main factors that paves the way to excellence. Enya et al. (2018) talked of the influence of reliability on the organizational performance and management. The authors noted that reliability within organization can help in achieving the best managerial results, that way an organization might be a good candidate to achieve excellence. Werner (2012) on the other hand presented the issue of reliability as a source of risk management approach. The author stated that with good reliability framework, the organization might be more able to react to sudden risks and unpredicted situations which will help it in forming the best route for excellence within its performance.

\section{c) Responsiveness and Organizational Excellence}

Analysis of current study revealed that responsiveness scored the highest level of influence with an $\mathrm{R}$ value of $\left(.540^{\mathrm{a})}\right.$ referring to this variable as the most influential variable among the service quality dimensions. From that point, it can be noted that organization's responsiveness play a role in defining the degree of interaction whether it was internal or external. The degree of responsiveness with clients can make the change and can increase the level of customer satisfaction leading to organizational excellence. Homburg et al. (2007) agreed on that same point, they argued that the notion of responsiveness can be one of the drivers of organizational excellence; through responsiveness the organization is basically able to build cognitive relations with its internal and external environment. Based on that, it is able to develop an approach that enables her to increase customer and employee satisfaction, better its relation with the market and have a high level of competitive advantage. Sahoo and Sahu (2009) stated that organizations usually can reach excellence through following good quality management strategies that throws its influence on both internal and external environment. However, the internal environment is what develops the external one, based on that, responsiveness can develop the degree of employee engagement which can lead to organizational excellence.

The same was presented by Braithwaite (2015) who saw that responsiveness can increase the level of environmental prosperity within the organization; it enables the organization to face risks in a better approach, deal with competitors in a good way which can pave its way to excellence.

\section{d) Assurance as a Driver for Organizational Excellence}

Assurance in service quality refers to the ability of organization's employees to show courtesy and their ability to deal with customers with confidence and trust. This variable of service quality is one of the most influential variables that may influence how customers see the organization and how they evaluate its services. In that sense, assurance appeared to be influential with an $\mathrm{R}$ value of $\left(.415^{\mathrm{a}}\right)$ given that fact that is has to do with how 
employees deal with customers. McGregor (2004) argued that assurance is one of the practices that have the ability to create an excellent service. The author saw that assurance is one of the variables that have a direct impact on customers' psychology which leads as a result to more customer satisfaction.

Goetsch and Davis (2014) argued that assurance is a form of a development tool for the service; it can be seen as a source of quality management that can lead to what is called management excellence. Du Plooy and De Jager (2007) argued that the idea of assurance can be applied in the services. It can help in creating a form of unification in the way employees deal with customers and how they provide the service to them, this unification can encourage both parties to develop a good sense of acceptance and satisfaction which can also lead to excellence.

\section{e) Empathy Role in Creating Excellence}

Empathy in service quality refers to the organization's ability to give personal and individualized attention to its customers. Customer satisfaction in fact is among the most influential factors that may drive the organization to excellence. When customers are satisfied, it is more probably that their loyalty to the organization will increase, and the competitive advantage will also increase due to the organizations sand within the market.

\section{Conclusion}

Results and discussion of current study have made sure that there is basically a relationship that gathers between service quality and organizational excellence. There have made indications that through the analysis and the previous studies that service quality has the ability to influence the organizational outcome. This can be measured through the nature of service presented, degree of customer satisfaction and the way the organization manages its internal process, not to mention that this influence can be read through the level of the organization's position within the external market. In other meaning, the more the service is aligned with the consumers' needs and expectation; the more it is able to deliver the organization into the shore of high performance and as a result excellence.

This idea was agreed on by Nilsson et al. (2001) who found a relationship gathering between service quality and consumer satisfaction in relation to business results. Also, Khurshid and Awan (2017) brought the idea from a different perspective; they argued that service quality can influence the organizational culture which leads to customer satisfaction; the gathering between those aspects can deliver the organization to excellence. This can happen through the gathered efforts of quality management, service quality, consumer satisfaction and the overall results of better performance; Ariani (2015) appeared to agree on such a relationship.

As for the variables of service quality, results indicated that responsiveness appeared to be the most influential variable on organizational excellence; in that sense, responsiveness refers to the willingness of the employees to present prompt services to clients and the time frame of these services. Shelton et al. (2011) noted to the fact that service quality and basically responsiveness are among the foundations of reaching organizational excellence. This can be indicated through the influence that service quality may throw on many sides of the organization including internal culture, employee satisfaction and consumers' satisfaction. Through the application of service quality dimension an organization may be able to develop all of its aspects that can develop its performance and reach organizational excellence.

Taylor and Baker (1994) also supported that same idea, they stated that taking care of quality, applying quality management strategies and making sure that the level of services within the organization matches the consumers' needs and expectations are among the milestones that an organization needs to follow in order to reach organizational excellence.

\section{Recommendation}

According to the analysis, it was found out that service quality among its dimensions was found to be influential when it comes to organizational excellence. From that point, current study presented the following theoretical recommendations:

- Organizations and specially banks which present financial services to clients should give more attention to the employees' awareness in its role in influencing the performance of the bank as a whole.

- Increase training course and workshops for employees in order to develop their service presenting skills.

- Quality management is a key issue; CRM should be connected to quality management.

- Develop the organizational culture in a way that fosters quality related issues. 
- Makes sure that employees are satisfied with their job environment as it can help in satisfying customers leading to organizational excellence.

- Expose employees to conferences, seminars and workshops that enable them to foster the culture of responsiveness as it appeared to be influential when it comes to organizational excellence.

\section{References}

Abasi, M. R., \& Esmaeeli, M. (2012). Organization Excellent and Self Assessment through Organization Excellence Model. Global Journal of Management and Business Research, 12(5).

Agarwal, A., \& Vrat, P. (2016). A bio-inspired model of organizational excellence. Journal of Advances in Management Research, 13(2), 130-153. https://doi.org/10.1108/JAMR-12-2015-0089

Ananth A, et al (2011), Service Quality Gap Analysis in Private Sector Banks. A Customer Perspective. Indian Journal of Commerce and Management Studies, 2(1), 245-253.

Ariani, D. W. (2015). Employee Satisfaction and Service Quality: Is There Relations?. International journal of business research and management, 6(3), 33-44.

Arussy, L. (2008). Excellence Every Day : Make the Daily Choice-- Inspire Your Employees and Amaze Your Customers. CyberAge Books/Information Today.

Babakus, E., \& Boller, G. W. (1992). An empirical assessment of the SERVQUAL scale. Journal of Business Research, 24(3), 253-268. https://doi.org/10.1016/0148-2963(92)90022-4

Berry, L. L., Parasuraman, A., \& Zeithaml, V. A. (1994). Improving service quality in America: lessons learned. Academy of Management Perspectives, 8(2), 32-45. https://doi.org/10.5465/ame.1994.9503101072

Bowden, P. (2000). Delivering organizational excellence by employee values management. Total Quality Management, 11(4-6), 636-640. https://doi.org/10.1080/09544120050007995

Brady, M. K., \& Cronin Jr, J. J. (2001). Some new thoughts on conceptualizing perceived service quality: a hierarchical approach. Journal of Marketing, 65(3), 34-49. https://doi.org/10.1509/jmkg.65.3.34.18334

Brady, M. K., Cronin Jr, J. J., \& Brand, R. R. (2002). Performance-only measurement of service quality: a replication and extension. Journal of Business Research, 55(1), 17-31.

https://doi.org/10.1016/S0148-2963(00)00171-5

Braithwaite, J. (2015). Responsive excellence. Penn Program on Regulation's Best-in-Class Regulator Initiative.

Brown, T. J., Churchill Jr, G. A., \& Peter, J. P. (1993). Improving the measurement of service quality. Journal of Retailing, 69(1), 127-139. https://doi.org/10.1016/S0022-4359(05)80006-5

Cameron, K. S., \& Quinn, R. E. (2011). Diagnosing and changing organizational culture: Based on the competing values framework. John Wiley \& Sons.

Cerman, J. (1990). Consumer perceptions of service quality: An assessment of the SERVQUAL dimensions. Journal of Retailing, 66(1), 33-55.

Chang, M., Jang, H. B., Li, Y. M., \& Kim, D. (2017). The relationship between the efficiency, service quality and customer satisfaction for state-owned commercial banks in China. Sustainability, 9(12), 2163. https://doi.org/10.3390/su9122163

Chang, M., Jang, H., Li, Y., \& Kim, D. (2017). The Relationship between the Efficiency, Service Quality and Customer Satisfaction for State-Owned Commercial Service Quality Dimensions and Customers' Satisfactions of Banks in Egypt.

Chess, C. (1999). Model of Organizational Responsiveness to Stakeholders, A. Risk, 10, 257.

Collins, J. C., \& Collins, J. (2001). Good to great: Why some companies make the leap... and others don't. Random House.

Cronin, J. J., \& Taylor, S. A. (1992). Measuring service quality: a reexamination and extension. Journal of Marketing, 56, 55-68. https://doi.org/10.2307/1252296

Dabholkar, P. A., Thorpe, D. I., \& Rentz, J. O. (1996). A measure of service quality for retail stores: scale development and validation. Journal of the Academy of MarketingScience, 24(1), 3-16. https://doi.org/10.1007/BF02893933

Darling, R. J., \& Nurmi, R. (1995). Downsizing the Multinational Firm: Key Variables for Excellence. Leadership \& Organizational Development Journal, 16(5), 22-28. 
https://doi.org/10.1108/01437739510088509

Dotchin, J. A., \& Oakland, J. S. (1994). Total quality management in services. International Journal of Quality \& Reliability Management, 11(3), 27-42. https://doi.org/10.1108/02656719410056468

Du Plooy, T., \& De Jager, J. (2007). Measuring tangibility and assurance as determinants of service quality for public health care in South Africa. Professional Accountant, 7(1), 96-111.

Duncan, E., \& Elliot, G. (2002). Customer service quality and financial performance among Australian retail financial institutions. Journal of Financial Services Marketing, 7(1), 25-41. https://doi.org/10.1057/palgrave.fsm.4770070

El Saghier, N. M. (2015). Managing Service Quality: Dimensions of service quality: a study in Egypt. Managing Service Quality, 9.

Enya, A., Pillay, M., \& Dempsey, S. (2018). A systematic review on high reliability organisational theory as a safety management strategy in construction. Safety, 4(1), 6. https://doi.org/10.3390/safety4010006

Finn, D. W., \& Lamb Jr, C. W. (1991). An Evaluation of the SERVQUAL Scales in a Retailing Setting. Advances in consumer research, 18(1), 483-490.

Frost, F. A., \& Kumar, M. (2000). INTSERVQUAL-an internal adaptation of the GAP model in a large service organisation. Journal of Services Marketing, 14(5), 358-377. https://doi.org/10.1108/08876040010340991

Goetsch, D. L., \& Davis, S. B. (2014). Quality management for organizational excellence. Upper Saddle River, NJ: pearson.

Harrington, H. (2005). The five pillars of organizational excellence. Handbook of Business Strategy, 6(1), 107-114. https://doi.org/10.1108/08944310510557116

Homburg, C., Grozdanovic, M., \& Klarmann, M. (2007). Responsiveness to customers and competitors: the role of affective and cognitive organizational systems. J. Mark., 7l(3), 18-38. https://doi.org/10.1509/jmkg.71.3.18

Hui, K. H., \& Chuan, T. K. (2002). Nine approaches to organizational excellence. Journal of Organizational Excellence, 22(1), 53-65. https://doi.org/10.1002/npr.10053

Hussain, M., Khalid, T. H., \& Waheed, S. (2010). Factors That Lead Organizations To Achieve Business Excellence. Journal of Quality and Technology Management, VI(1), June, 2010, 39-55.

Hussain, T., Khalid, M., \& Waheed, S. (2010). Factors that lead organizations to achieve business excellence. Journal of Quality and Technology Management, 6(1), 1-17.

Irani, Z., Beskese, A., \& Love, P. E. D. (2004). Total quality management and corporate culture: constructs of organisational excellence. Technovation, 24(8), 643-650. https://doi.org/10.1016/S0166-4972(02)00128-1

Kazemi, M. A. A., Eshlaghy, A. T., \& Tavasoli, S. (2011). Developing the product strategy via product life cycle simulation according to the system dynamics approach. Applied Mathematical Sciences, 5(17), 845-862.

Khurshid, F., \& Awan, M. U. (2017). Service Quality and Organizational Culture as Predictors of Faculty Job Satisfaction. Pakistan Business Review, 19(2), 499-517.

McAdam, R. (2000). Quality models in an SME context. International Journal of Quality and Reliability Management, 17, 305-323. https://doi.org/10.1108/02656710010306166

McGregor, F. (2004). Excellent Libraries: A quality assurance perspective. In Advances in librarianship (pp. 17-53). Emerald Group Publishing Limited.

McMaulle, R., Brown, P., \& Cliffe, R. (2001). "Organizational culture and quality improvement”, International Journal of Operation and Production Management, 21(3), 302-326. https://doi.org/10.1108/01443570110364614

McNamara, C. (1997). Organizational Excellence, Business \& Economic Review, Jul-Sep 1997, pp.19-22

Nilsson, L., Johnson, M. D., \& Gustafsson, A. (2001). The impact of quality practices on customer satisfaction and business results: product versus service organizations. Journal of Quality Management, 6(1), 5-27. https://doi.org/10.1016/S1084-8568(01)00026-8

Parasuraman, A., Zeithaml, V. A., \& Berry, L. L. (1985). A conceptual model of service quality and its implications for future research. the Journal of Marketing, 41-50.

Parasuraman, A., Zeithaml, Valerie A., \& Berry, L. L. (1988). "SERVQUAL: a multiple-item scale for measuring 
consumer perceptions of service quality," Journal of Retailing, 64(1), 12-40

Purcărea, T. V., Ioan-Franc, V., \& Raţiu, M. P. (2010). Achieving Excellence through Memorable Traveler Experience and Challenges, Opportunities and Solutions for Romanian Travel and Hospitality Industry. Revista Romana de Economie, 29(1).

Purcărea, V. L., Gheorghe, I. R., \& Petrescu, C. M. (2013). The assessment of perceived service quality of public health care services in Romania using the SERVQUAL scale. Procedia Economics and Finance, 6, 573-585. https://doi.org/10.1016/S2212-5671(13)00175-5

Sadek, D. M., Zainal, N. S., Taher, M. S. I. M., Yahya, A. F., Shaharudin, M. R., Noordin, N., ... Jusoff, K. (2010). Service quality perceptions between cooperative and Islamic Banks of Britain. American Journal of Economics and Business Administration, 2(1), 1. https://doi.org/10.3844/ajebasp.2010.1.5

Sahoo, C. K., \& Sahu, G. (2009). Effective employee engagement: The mantra of achieving organizational excellence. Management and labour studies, 34(1), 73-84. https://doi.org/10.1177/0258042X0903400105

Sasmita, P., \& Nayantara, P. (2003). Measuring effectiveness of TQM training: an Indian study, International Journal of Training and Development, 7(3), 203-216. https://doi.org/10.1111/1468-2419.00181

Shelton, C. D., Darling, J. R., \& Walker, W. E. (2002). Foundations of organizational excellence: leadership values, strategies, and skills. LTA, 1(02), 46-63.

Shelton, K. (2011). A review of paradigm for evaluating the quality of online education programs. Online Journal of Distance Learning Administration, 14(1). Available: http://www.westga.edu/ distance/ojdla/spring141/shelton141.html

Shirvani, A., \& Javad Iranban, S. (2014). Organizational excellence performance and human force productivity promotion: A case study in South Zagros Oil and Gas Production Company, Iran. European Online Journal of Natural and Social Sciences: Proceedings, $2(3$ (s)), 3010.

Taylor, S. A., \& Baker, T. L. (1994). An assessment of the relationship between service quality and customer satisfaction. Journal of retailing, 70(2), 163-178. https://doi.org/10.1016/0022-4359(94)90013-2

Tohidi, H., \& Jabbari, M. (2012). Service Quality Evaluating Models. Journal of Social and Behavioral Sciences, $3(1)$.

Werner, J. (2012). High reliability organization theory as an input to manage operational risk in project management.

\section{Copyrights}

Copyright for this article is retained by the author(s), with first publication rights granted to the journal.

This is an open-access article distributed under the terms and conditions of the Creative Commons Attribution license (http://creativecommons.org/licenses/by/4.0/). 